\title{
The effect of corruption on FDI: a parametric and non-parametric analysis
}

\author{
Marco R. Barassia, Ying Zhou ${ }^{\mathrm{a}, \mathrm{b}, *}$ \\ ${ }^{a}$ Department of Economics, University of Birmingham, Birmingham, UK \\ ${ }^{\mathrm{b}}$ Economics and Strategy Group, Aston Business School, Birmingham, UK
}

\begin{abstract}
This paper analyses the effect of corruption on Multinational Enterprises' (MNEs) incentives to undertake FDI in a particular country. We contribute to the existing literature by modelling the relationship between corruption and FDI using both parametric and non-parametric methods. We report that the impact of corruption on FDI stock is different for the different quantiles of the FDI stock distribution. This is a characteristic that could not be captured in previous studies which used only parametric methods. After controlling for the location selection process of MNEs and other host country characteristics, the result from both parametric and nonparametric analyses offer some support for the 'helping-hand' role of corruption.
\end{abstract}

JEL Classification: F23

Keywords: Corruption, FDI, parametric, non parametric, MNEs' location choice

${ }^{*}$ Corresponding author: Tel.: +44 121 2043038; Fax: +44 1212043306.

Email.address: y.zhou8@aston.ac.uk (Y.Zhou). 


\section{Introduction}

Corruption is not unusual in international business; instead it can be a routine practice for investors, especially in developing countries (Transparency International (TI) Bribe Payers Index 2010, Work Bank 1999). The subsidiaries of multinational enterprises (MNEs) are the main suppliers of bribes all over the world (TI 2006), and this has been long acknowledged by numerous International Organisations such as the OECD, the World Bank, the IMF and the UN (Tanzi 1998 and Svensson 2005). At the same time, MNEs are also recognised for their significant contribution to the fight against worldwide corruption (OECD 1999, TI 2006).

In the past three decades, despite a considerable number of theoretical and empirical studies, there is still no agreement on the direction of the impact of corruption on firms' investment decisions. Earlier studies on this issue can be broadly categorised into two main strands. On one hand, the 'grabbing-hand' theory of corruption, supported by Shleifer and Vishny (1992, 1993), Bliss and di Telia (1997) and Aidt (2003), claims that corruption in an economy acts like a grabbing hand that increases the costs of carrying out business activities. In a survey of international business managers by Kaugmann (1997) the costs of investing in a more corrupt host country were shown to be as much as $20 \%$ higher than those of a less corrupt one. By this line of reasoning corruption in a host country will increase the costs of foreign investors and will hence discourage FDI. This argument is supported by the empirical studies of Wei (2000a, 2000b), Drabek and Payne (2001), Habib and Zurawicki (2002), Javorcik and Wei (2009), Egger and Winner (2006) Busse and Hefeker (2007) and Hakkala et al. (2008) for both developed and developing countries.

On the other hand, Lui (1985), Beck and Maher (1986) Bjorvatn and Soreide (2005) and Saha (2000) argue that corruption can be a 'helping-hand' in the economy. Using different theoretical models, they show that rather than an obstacle to business, corruption could be an efficient 'lubricant' for rigid economic regulation and red-tape. This could be especially true for international business operating in developing countries. By bribing the host government, MNEs can get around regulations and red-tape and hence benefit from monopoly or near monopoly power (Tanzi 1998). Therefore, as reported by Wheeler and Mody (1992) and Egger and Winner (2005), corruption in the host country will not necessarily discourage FDI from foreign firms.

In this paper we use a large panel from 20 OECD FDI source countries into 52 developed and developing host countries between 1996 and 2003 to empirically reassess the impact of corruption on the MNE location decision question using both parametric and non-parametric methods. In the process, we will stress the heterogeneous relationship between corruption and FDI. In particular, we show that after controlling for the other determinants of FDI including the important role of the interdependence between MNEs' location and investment level decisions, the impact of FDI differs for countries with existing high and low stocks of FDI. This might help to explain the inconclusive results on the effect of corruption on FDI observed by earlier studies.

Earlier empirical studies such as Wheeler and Mody (1992), Drabek and Payne (2001), Egger and Winner $(2005,2006)$ and Busse and Hefeker (2007) analysed the impact of corruption on the 
level of FDI without controlling for the host country selection process of the MNEs. The estimated relationship would be unbiased only if the countries with positive FDI are randomly selected to become a host country. However, in reality the countries that have positive FDI are not randomly chosen, instead they have been selected by the MNEs. In this case, if the error terms from the FDI location and level estimations are correlated, then to estimate the impact of corruption on FDI levels without considering the probability of that country been selected as a host country would be biased (Heckman, 1979) ${ }^{1}$. Recently, Wei (2000a, 2000b) and Hakkala et al. (2008) take this point into account and integrated the probability of a country becoming an FDI host country into the estimation of the MNEs' FDI stock level choice.

The studies mentioned above adopt traditional parametric regression methods to analyse the relationship between corruption and FDI. They study the correlation at mean values, which effectively assumes the effect of corruption on FDI to be homogenous across all the quantiles of the FDI distribution. On the other hand, when the relationship between corruption and FDI are heterogeneous among different quantiles of the FDI distribution, using parametric estimation would mask the variations in the relationship. This means that the inconclusive results from the previous parametric studies might not necessarily be contradictory, but instead might represent the different relationships between corruption and FDI for different quantiles of FDI distribution.

In this study, in order to shed some light on the possible impact of corruption on MNEs' investment decision we will also use non parametric methods to complement the results obtained by using parametric methods. Firstly, we will analyse the location choice of MNEs given the different levels of corruption and other characteristics in the host countries. This study is one of the few studies to pay attention to the question of the possible effect of corruption on the probability of FDI taking place. ${ }^{2}$ Next, we try to determine the direction and magnitude of the effect of corruption in the host country on the level of FDI stock invested, after MNEs decided to invest there. ${ }^{3}$ Following Hakkala et al. (2008), in this paper Heckman's (1979) method is employed. Secondly, after re-examining the relationship between corruption and FDI with parametric methods, we provide a novel way to analyse the impact of corruption on the level of FDI stock by employing non-parametric methods. As far as we are aware, this is the first paper to adopt non-parametric techniques to study the impact of corruption on unconditional and conditional FDI stock level, allowing us to identify possible heterogeneity and draw more rigorous conclusions about this complex relationship.

The rest of the paper is organised as the follows. In section 2 we describe the parametric and non-parametric methods that are used to analyse the impact of corruption on FDI decisions (i.e.

\footnotetext{
${ }^{1}$ Sample selection error correction is very rare in international economics, because some believed that by using fixed-effect panel estimation, the possible correlation between the selection processes for location and FDI stocks can be corrected. But as pointed out by Verbeek and Nijman (1992), fixed-effect panel estimation can only correct sample selection bias if the correlation between the error terms from the selection process for location and FDI stocks are correlated through time-invariant unobservable variables. This means that if the error terms are not correlated in this particular fashion, the results observed from fixed-effect panel estimation will still be biased.

2 This problem has only been studied by Javorcik and Wei (2002) and Hakkala et al. (2008) using firm level data.

${ }^{3}$ Even though empirical research on the possible effect of corruption on FDI has been undertaken for years, a uniform framework for studying this issue is still lacking. In this paper we follow the approach employed by Wei (2000a and 2000b), Egger and Winner $(2005,2006)$ and Hakkala et al. (2008) to focus on FDI stock.
} 
the decision of whether to invest in a certain country and how much to invest) and the data that is used. We discuss the results from our estimations in section 3. Section 4 concludes.

\section{Methodology and data}

\subsection{Methodology}

There are two main streams of theory regarding the motivations for FDI and the key factors that could determine the level of FDI in a host country. The first one is the 'Vertical Integration' theory of FDI, which assumes that MNEs break the production process into stages and allocate different stages to different locations in order to take advantage of the different factor endowments. Among these, Helpman $(1984,1985)$ suggests that the differences in production costs such as labour costs could be strong determinants of the FDI level.

The second stream is called the 'Horizontal Integration' theory of FDI (Horstmann and Markusen 1992 and Brainard 1993) and aims to explain the high level of FDI between similar or even identical countries, and assumes that the primary motivation for MNEs is to gain market access rather than to take advantage of differences in factor endowments. This stream of theory predicts that the host country's market size and trade cost would be vital in determining the level of FDI.

Here, we will follow the majority of the empirical studies in the literature and control for the factors that are suggested by both streams of theory as mentioned above (Wei 2000a, Wei 2000b, Egger and Winner 2005, 2006, Hakkala et al. 2008). Although the impact of these factors on MNEs' incentive to undertake FDI is well accepted in the theoretical literature (Helpman 1984, 1985, Horstmann and Markusen 1992, Brainard 1993), as MNEs' incentive for FDI cannot be measured directly, the actual effect of these factors is difficult to quantify in practice. Instead we can only observe whether FDI takes place or not. Following Hakkala et al. the relationship between corruption and the probability of FDI taking place is represented as below:

$$
\begin{aligned}
I_{i j t} & =1 \text { if } I_{i j t}^{*}>0 \\
I_{i j t} & =0 \text { otherwise } \\
\text { where } I_{i j t}^{*} & =b_{1} C_{i t-1}+\pi_{1} X_{i t-1}+v_{i j t}
\end{aligned}
$$

Normally MNEs make their investment decisions at time $t$ based on past information, hence, it is reasonable to assume that the probability of a source country $j$ investing in a host country $i$ at time $t$ is a function of explanatory variables in the previous period (i.e. $t-1){ }^{4}$ In equation (1) above, $I_{i j t}^{*}$ is the latent variable that depends on a matrix of host country factors from both the 'Vertical Integration' and 'Horizontal Integration' theories mentioned earlier, which are captured in $X_{i t-1}$, and host country corruption level $C_{i t-1}$. And $I_{i j t}$ represents the likelihood of the foreign investors $(j)$ invest in the host country $(i)$ at time $t$, and takes the value 1 if the latent incentive variable $I_{i j t}^{*}$ is positive, and 0 otherwise. The coefficient $b_{1}$ measures the marginal effect (after controlling for the other relevant factors) of a change in the level of corruption in a

\footnotetext{
${ }^{4}$ This is true for all variables except the measure for the effectiveness of the OECD Anti-bribery Convention, which
} is assumed to affect FDI decisions from 1999 onwards, hence enters the estimation equation at period $t$ not $t-1$. 
host country on the probability of the foreign investor from country $j$ investing in this country (country i). As discussed earlier, the latent variable $I_{i j t}^{*}$ would be negatively related to 'grabbinghand' corruption and positively correlated to 'helping-hand' corruption in the host country $i$, therefore the direction of the overall effect of corruption on the probability of a particular source-host pair to become active (i.e. the sign of $b_{1}$ ) will be determined by the type of corruption that is dominant.

$v_{i j t}$ is the error term from the estimation of probability equation (1) and we assume that $v_{i j t}$ satisfies the following conditions: $E\left(v_{i j t} \mid X_{i t-1}\right)=E\left(v_{i j t} \mid C_{i t-1}\right)=0$ and $v_{i j t} \sim N\left(0, \sigma_{v}^{2}\right)$. From equation (1) and the assumptions on the error term distribution, we derive the equation for estimating the impact of corruption in the host country at $t-1$ on the probability of FDI taking place at time $t$, that is:

$$
P\left(I_{i j t}=1 \mid C_{i t-1}, X_{i t-1}, v_{i j t}\right)=\Phi\left(b_{1} C_{i t-1}+\pi_{1} X_{i t-1}\right) .
$$

where $\Phi$ is the cumulative distribution function. After investigating the effect of corruption on the probability of FDI taking place, we estimate the impact of corruption on the level of FDI stock invested in the host country. Following Hakkala et al. (2008) to counter the possible correlation between the error terms in the MNEs' location and FDI stock estimations, we shall use Heckman's method and estimate the incentive and FDI level decisions of foreign firms simultaneously. The complete econometric model can therefore be written as:

$$
\begin{gathered}
I_{i j t}=1 \text { if } I_{i j t}^{*}>0 \\
I_{i j t}=0 \text { otherwise } \\
\text { where } I_{i j t}^{*}=b_{1} C_{i t-1}+\pi_{1} X_{i t-1}+v_{i j t} \\
\log K_{i j t}=b_{2} C_{i t-1}+\pi_{2} Z_{i t-1}+u_{i j t} \text { if } I_{i j t}=1
\end{gathered}
$$

where $\log K_{i j t}$ represents the $\log$ value of FDI stock invested by country $j$ in country $i$ at time $t$ and $C_{i t-1}$ as before measures the corruption level in the host country. The coefficient $b_{2}$ measures the partial marginal effect of a change in the level of corruption in a host country on the level of foreign investment from country $j$ investing in this country (country $i$ ). As discussed earlier, the FDI stock would be negatively correlated with 'grabbing-hand' corruption and positively correlated to the 'helping-hand' corruption in the host country $i$, therefore similar to the case of the FDI location estimation, the direction of the effect of $C_{i t-1}$ on $\log K_{i j t}$ will be determined by the type of corruption that has the dominant effect.

Again, we include factors that control both the 'Horizontal' and 'Vertical Integration' theories of FDI (see Wheeler and Mody 1992, Wei 2000a, 2000b, Egger and Winner 2005, 2006), denoted by $Z_{i t-1}$. This includes measures of production costs, trade costs, and the market size of the host country. It is worth noticing that for identification purposes in equation (3), at least one of the variables in matrix $X_{i t-1}$ must be excluded from the variables in the matrix $Z_{i t-1} .{ }^{5}$ The error term in regression for the level of FDI (i.e. $u_{i j t}$ ) is assumed independent from corruption (i.e. $\left.C_{i t-1}\right)$ and the other control variables (i.e. $Z_{i t-1}$ ), and distributed with mean zero and variance $\sigma_{u}^{2}$.

${ }^{5}$ We will discuss the variables used in matrices $Z_{i t-1}$ and $X_{i t-1}$ in more detail in the result section. 
As explained in the introduction, the parametric methods used by previous studies only focus on the relationship in mean between the variables, which might mask potential heterogeneity in the relationship between corruption and FDI stock. To fully exploit the information contained in the entire FDI distribution, in particular the possible variations in the impact of corruption on FDI among host countries with different FDI stock levels, we perform a stochastic dominance test in first degree. ${ }^{6}$ This allows us to study the impact of corruption for countries in every quantile of the FDI stock distribution, therefore helping to reveal the possible heterogeneity in the impact of corruption on countries with different levels of FDI stock.

Let $\Omega_{1}$ and $\Omega_{2}$ denote the cumulative distribution function of FDI stock of two groups of countries that we are trying to compare. In particular, we assume one sample of $\omega_{1}, \ldots, \omega_{n}$ to be randomly drawn from a FDI stock level cumulative distribution $\Omega_{1}$ from countries with relatively low level of corruption; and that another sample $\omega_{n+1}, \ldots, \omega_{N}$ is drawn from another FDI stock level cumulative distribution $\Omega_{2}$ from countries with relatively high levels of corruption. If for any given percentile of FDI stock the observations from the cumulative distribution $\Omega_{1}$ (i.e. less corrupt countries) are at least as large as the observations from the cumulative distribution $\Omega_{2}$ (i.e. more corrupt countries) of the same percentile, then the cumulative FDI distribution $\Omega_{1}$ stochastically dominates the cumulative distribution of $\Omega_{2}$ in the first degree. This means the FDI stock level would be higher for less corrupt countries for all quantiles, which implies corruption is negatively correlated with FDI stock in the host country for all quantiles of FDI stock distribution.

In formal terms $\Omega_{1}$ stochastically dominates $\Omega_{2}$ if $\Omega_{1}(\omega)-\Omega_{2}(\omega) \leq 0$ holds for all $\omega \in \mathfrak{R}$ and the inequality holds strictly for at least some observation $(\omega)$. To test for a possible stochastic dominance relationship between $\Omega_{1}$ and $\Omega_{2}$ in the first degree, both one-sided and two-sided Kolmogorov-Smirnov (hereafter KS) tests are employed. First a two-sided KS test will be used to test the null hypothesis that these two cumulative distributions are significantly different from each other.

$$
\begin{aligned}
& H_{0}: \Omega_{1}(\omega)-\Omega_{2}(\omega)=0 \text { for all } \omega \in \mathfrak{R} \\
& H_{1}: \Omega_{1}(\omega)-\Omega_{2}(\omega) \neq 0 \text { for all } \omega \in \mathfrak{R}
\end{aligned}
$$

Next a one-sided KS test is performed to test for possible first degree dominance. Specifically, we test the hypotheses:

$$
\begin{aligned}
& H_{1.1}: \Omega_{1}(\omega)-\Omega_{2}(\omega)<0 \text { for all } \omega \in \mathfrak{R} \\
& H_{1.2}: \Omega_{1}(\omega)-\Omega_{2}(\omega)>0 \text { for all } \omega \in \mathfrak{R}
\end{aligned}
$$

If the null hypothesis and $H_{1.2}$ can be rejected while the alternative $H_{1.1}$ cannot be rejected for the given sample, we conclude that the cumulative distribution $\Omega_{1}$ stochastically dominates the cumulative distribution $\Omega_{2}$ in the first degree (i.e. corruption is negatively correlated with FDI

\footnotetext{
${ }^{6}$ As the main interest of this paper is on the impact of corruption on FDI investment level decision made by MNEs, our non-parametric study will be confined to first degree stochastic dominance. The study of higher degree stochastic dominance relationship is beyond the scope of current study.
} 
stock levels as suggested by 'grabbing-hand' theory of corruption); otherwise if the null hypothesis and $H_{1.1}$ can be rejected but $H_{1.2}$ cannot be rejected, we conclude that the cumulative distribution $\Omega_{2}$ stochastically dominates the cumulative distribution $\Omega_{1}$ in the first degree (i.e. corruption is positively correlated with FDI stock levels as suggested by the 'helping-hand' theory of corruption). By studying the entire distribution, the KS test can provide more robust conclusions on the impact of corruption on FDI stock levels for countries at different quantiles of FDI stock distribution.

To implement the one and two-sided KS tests, we first observe the two and one-sided KS test statistics from the empirical cumulative distributions, which can be written as the follows respectively:

$$
\begin{aligned}
K S_{2} & =\sqrt{\frac{n m}{N}} \max _{1 \leq i \leq N}\left|\widehat{\Omega_{1}}\left(\omega_{i}\right)-\widehat{\Omega_{2}}\left(\omega_{i}\right)\right| \\
K S_{1} & =\sqrt{\frac{n m}{N}} \max _{1 \leq i \leq N}\left\{\widehat{\Omega_{1}}\left(\omega_{i}\right)-\widehat{\Omega_{2}}\left(\omega_{i}\right)\right\}
\end{aligned}
$$

Where $\widehat{\Omega_{1}}$ and $\widehat{\Omega_{2}}$ represent the empirical FDI stock distributions of the less and more corruption countries $\Omega_{1}$ and $\Omega_{2}$ respectively. $n$ and $m$ denote the number of observations in less and more corrupt countries and $N=n+m$.

Next the $p$-values for hypothesis tests are observed. As shown by Kolmogorov (1933) and Smirnov (1939) when the two distributions $\Omega_{1}(\omega)$ and $\Omega_{2}(\omega)$ are identically independently distributed (IID) with independent variances, then it is possible to obtain the relevant $p$-values using the asymptotic limiting distribution for the KS statistics. ${ }^{7}$ However, as a result of the strong correlation presented between current and past FDI stock levels and the panel nature of our dataset, pooling all the years together would violate the IID assumption. Hence, we will study the stochastic dominance relation for each year separately. ${ }^{8}$ To check for the robustness of our results we also adopt the method suggested by Massoumi and Heshmati (2000) and Linton et al. (2005) that allows general dependence by using sub-sample bootstrapping for the $p$-values. We conduct bootstrapping for the two groups of countries separately according to their corruption levels. It has been shown by Linton et al. (2005) that bootstrapping with a sub-sample is more desirable than bootstrapping with the combined sample as it provides a more accurate test on the boundary of the null. Our result is based on 1,000 sub-sample bootstrapping. This enables us to pool all the data together and make valid comparison of countries with different corruption levels over the years at the same time.

\subsection{The data}

\footnotetext{
7 Kolmogorov (1933) and Smirnov (1939) showed under the IID assumption the $p$-values can be found as $\lim _{N \rightarrow \infty} P\left(\sqrt{\frac{n m}{N}}\left(\Omega_{1}\left(\omega_{i}\right)-\Omega_{2}\left(\omega_{i}\right)\right) \leq Z\right)=1-2 \sum_{1}^{\infty}(-1)^{i-1} \exp \left(-2 i^{2} Z^{2}\right)$, see Conver (1999) for details. Delgado et al . (2002) shows when the IID assumption holds the $p$-values are also valid for residuals of regression.

${ }^{8}$ In Table 3 the $p$-values for pooled data will be reported alongside with each individual year, which are provided as a comparison to the $p$-values obtained from sub-sample bootstrapping. As shown by Linton et al. (2005) the $p$-value is valid for residuals from regression, hence can be used for investigating conditional FDI stock in current study.
} 
The FDI data is drawn from a sample of 20 OECD source countries and 52 host countries over the period 1996 to 2003, including both developed and developing countries from all over the world. ${ }^{?}$

We measure the dependent variable, the $\log$ FDI capital stocks (i.e. $\log K_{i j t}$ ) invested from country $j$ to country $i$ at time $t$ by the total bilateral FDI stocks at 1999 US dollars price measured using Purchase Power Parity (PPP). This is observed from the OECD International Direct Investment statistics.

The likelihood that investors in country $j$ would invest in country $i$ at time $t$ (i.e. $I_{i j t}$ ) is measured by an indicator variable which takes the value of unity if the level of bilateral FDI stock is positive and 0 otherwise.

In modelling both the probability to undertake FDI in a country as well as the stock of the FDI invested, we are interested in the effect of the level of corruption in host country $i$. This is measured by Transparency International's Corruption Perception Index (here forth TI's CPI) and World Bank's Governance Indicator, which are obtained as the average of results from surveys on corruption and have been widely used in the empirical literature in the field (Javorcik and Wei 2009 and Egger and Winner 2005, 2006). The TI's CPI ranges from 0 to 10 and the World Bank's Governance Indicator ranges from -2.5 to 2.5, with a lower value representing a more corrupt country, whilst a higher grade represents a cleaner host government. For explanatory simplicity, here both corruption measures are multiplied by -1 , so in this paper a larger corruption score represents a more corrupt host country. We shall use TI's CPI as the main measure for corruption and use the World Bank's Governance Indicator for a sensitivity check.

The effect of the OECD Anti-bribery Convention on MNEs' attitudes toward corruption in the host country can be tested by exploiting the time-dimension of our data. This convention was implemented in February 1999, and as a result we would expect MNEs to become more averse to corruption in the host country after 1999. In this paper, the effectiveness of this convention is tested by checking the sign and significance of the coefficient for an interaction term constructed by multiplying the indicator variable for post 1999 (this indicator equals 1 if the data was observed post 1999, and equals 0 otherwise) with the measure of corruption. The Antibribery convention would be effective in making MNEs more corruption averse if the coefficient for the interaction term is found to be negative and significant.

The primary control variables in the regression for both the probability to undertake FDI and that of FDI stock include the factors suggested by the 'Horizontal Integration' theory motioned before, which consists of the host country's market size measured by the host country's total population, GDP per capita, total GDP and its growth rates, which are observed from the World Bank's World Development Indicators. The openness of the country is taken from the Penn World Tables and is used as a proxy for the trade restrictions of the host country. Its effect on the probability of FDI is undetermined, as on one hand a lower level of trade restriction would increase the profit from exporting from country $j$ to $i$, thereby reducing the relative attractiveness

${ }^{9}$ A full list of countries used is provided in the appendix. 
of FDI as country $j$ 's MNEs' alternative strategy to supply country $i$; on the other hand a lower level of trade restriction would increase the profit from exporting from country $i$ to other countries, hence increase MNEs' incentive to invest in country $i$.

The production costs of the foreign firm as suggested by 'Vertical Integration' theory are measured by the real average wage rate in the manufacturing section in each country from OECD Labour Force Statistics and the maximum marginal corporation tax rate obtained from the World Tax Database. The real average wage rate is included as the main measure for labour costs, while the marginal tax rate is used as measure for operation costs, both of which have been reported as important factors in determining FDI location and FDI stock levels in previous studies (Wei 2000a and 2000b).

Wei (2000b) shows that the attitude of the host government towards foreign firms in terms of foreign exchange controls, exclusion from strategic sectors, exclusion from other sectors and restrictions on ownership share would dramatically reduce the MNEs' incentive for FDI. On the other hand, industry and geographic incentives, tax concessions, non-tax concessions and export incentives for MNEs would encourage FDI. To take the overall effect of these government policies into account we include the "net incentive" from Wei (2000b), which ranges from -4 to 4 , with a more positive number indicating a higher net incentive in the host country. We expect this variable to have a positive effect (sign) on the FDI stock level.

The potential effect of the host country's political system on the likelihood and level of FDI is also taken into consideration. This is done by including indices of overall democracy in the host country from the Polity IV project. The measure of democracy, called Polity2, ranges from -10 to 10 , where a higher number indicates a more democratic host country, and a lower number implies a more autocratic host country. Because more democratic countries tend to provide more protection to private property and investment from exploitation by the host government, the democracy measure is expected to be positively correlated with both the probability of becoming a host country and stock level of FDI. ${ }^{10}$

Recall that aside from the standard parametric analysis we also perform a non-parametric test on the distributions of FDI stock level in host countries with different corruption levels. To do so, we separate the host countries into two groups according to their corruption level relative to the sample mean. They will be called 'more corrupt' and 'less corrupt' host countries. We first study the effect of corruption on unconditional FDI levels by applying a stochastic dominance test on the bilateral FDI stock levels. Next, we regress FDI stock level against all the explanatory variables except corruption as in our parametric estimation. We then compare the residuals according to the corruption levels in the host countries. This effectively provides us with the impact of corruption on the two groups of otherwise identical countries in attracting different levels of FDI investment. The effect of corruption on FDI would be negative for all FDI stock levels, if the unconditional/conditional FDI distributions of the 'less corrupt' host countries stochastically dominate the 'more corrupt' host countries in the first degree.

Furthermore, by analysing the changes in the pattern of this dominance relationship among our sample years, in particular the pre OECD Anti-bribery Convention periods (i.e. 1996-1999) and

${ }^{10}$ See the Polity IV data manual for detailed definition and explanation. 
post convention periods (i.e. 2000-2003), we can draw some conclusions on the effectiveness of the OECD Anti-bribery convention in making MNEs more corruption averse. If the convention is effective then the stochastic dominance of the 'less corrupt' host countries over the 'more corrupted' host countries in attracting FDI would become stronger in later years.

Table 1 summarises the key variables in our study. It shows on average the probability of a particular FDI source-host country pair becomes active in our sample between 1996 and 2003 is around $71 \%$. For an active FDI source-host country pair, on average it attracts around 2052.62 million US dollar worth of investment stock. The distribution of FDI stock is rather asymmetric and skewed to the left with the minimum FDI stock of 2 million US Dollar from Poland to Norway and the maximum FDI stock of 4722 million US Dollar from the Netherlands to Hong Kong. Moreover, the distribution of the corruption level in the host country is also quite diverse with the inverse Corruption Perception Index for the most corrupt country (i.e. Indonesia) being -0.57 , whilst the least corrupt country (i.e. Finland) being -10 . Given the diverse distribution of FDI stock and corruption across countries, the assumption of a homogenous relationship between corruption and FDI seems to be particularly restrictive, and this provides an extra incentive for the use of non-parametric methods in our study since it allows identification and modelling of such heterogeneity in the relationship corruption/FDI.

$<<$ Table 1 about here $>>$

\section{Empirical results}

In this section the empirical results are reported and discussed in relation to previous studies.

\subsection{Corruption and the likelihood of FDIs}

First we study the effect of corruption on the likelihood of a country becoming a host country for FDI. The random effect panel probit estimation of equation (1) is reported in the two left hand side columns of table 2 .

In line with earlier studies (Javorcik and Wei 2009, Hakkala et al. 2008) the likelihood that FDI stocks take place in a host country is negatively affected by the level of corruption with marginal effects of around $-3 \%{ }^{11}$ In other words, on average, if corruption in a country improves from the level of Italy (5.3 in 2003) to that of Japan (7 in 2003), the probability of FDI stock taking place in the country would be increased by as much as 5.1 percent, which is significant both statistically and in terms of magnitude.

The results also show that since the implementation of the OECD Anti-bribery Convention, MNEs have not become more averse to the level of corruption in the host country. This provides empirical support to TI's claim of the limited impact of the convention in altering the investment choices of MNEs into corrupt host countries (TI 2006). The possible reason for this

\footnotetext{
11 The marginal effect (elasticity) is calculated at the mean value of the corruption levels and the other control variables .
} 
"counter-intuitive" result might be that since 1999, there has been a slight fall in the average corruption level worldwide, and therefore, when making their FDI decisions, MNEs might worry less about corruption than they did before. As a result, MNEs have become less averse to corruption in the host country when deciding on whether to invest in a country or not since $1999 .{ }^{12}$

$<<$ Table 2 about here $>>$

\subsection{Corruption and the level of FDI stock}

We now concentrate on the possible impact of corruption on the level of bilateral FDI stock as indicated by equation (3). Notice that in the estimation of the location selection process in equation (3) we include logged population and the growth rate of GDP as measures for market size and potential, whilst for estimation identification purpose, in the FDI stock level regression in equation (3) we use GDP per capita and GDP separately to control for market size. The results are shown in the two columns on the right of Table 2.

The table shows that the coefficients for the inverse Mills ratio are negative and significantly different from zero. This implies that any estimation of the relationship between the FDI level and corruption without taking into account the possible location selection process would produce biased estimates.

The estimates from the location selection equation are similar to the results discussed in the earlier section, which are shown in the bottom part of the two right hand side columns of table 2 . In particular, it is shown that a higher level of corruption in the host country would reduce the probability of a country being selected as a host country. Also, the OECD Anti-bribery Convention is not effective in discouraging MNEs from investing in a corrupt country.

The estimated effect of corruption and other variables on the level of FDI stock is represented in the top part of the right hand side columns of table 2. These show that, unlike for the estimates of the location selection equation discussed above, the impact of corruption on the level of FDI stock invested is positive and significant. This indicates that once MNEs have chosen a country as the host country, a higher corruption level in that country may increase FDI stock rather than reducing it, therefore providing support to the 'helping hand' theory of corruption $^{13}$. This result is similar to that of Wei (2000a, 2000b) who shows that the MNEs that undertake FDI are less corruption-averse than those that do not undertake FDI. It also offers

\footnotetext{
${ }^{12}$ This result is in line with the finding by Egger and Winner (2006).

${ }^{13} \mathrm{It}$ is worth noticing that when estimating the model without controlling for the location selection process the coefficients for corruption was negative and significant, which indicates a 'grabbing hand' effect of corruption. Also, without controlling for the location selection process, the OECD Anti-bribery convention has a positive and significant coefficient on FDI stock level, which indicates the ineffectiveness of the convention in reducing the amount of FDI MNEs' choose to invest in the corrupt host countries. These highlight the importance of controlling MNEs' location selection choice when estimating the effect of corruption and other variables on their FDI stock level. As the estimation without taking into the location selection process into account is biased, it is not reported in the paper but is available upon request.
} 
further empirical support to the claim of Campos et al. (2010) who suggested that corruption can be a 'wheel greaser' for the existing firms but a 'wheel sander' for new comers.

Furthermore, unlike for the location choice estimation, the coefficient for the OECD Antibribery Convention on the level of FDI stock is negative. This indicates some impact of the convention in making MNEs more corruption averse when choosing FDI level. Combining the above results with the earlier ones for the probability of FDI stock taking place, they show that since the implementation of the Anti-bribery Convention although MNEs are not more averse towards the level of corruption in the host country when choosing where to locate their investment, they are evidently more averse towards corruption in the host country, when deciding the level of capital to invest in that country.

Moreover, Table 2 shows that the traditional factors, such as openness, net restriction in the market and democracy in the host country can be important in determining the level of FDI stock in the host country.

\subsection{Non-parametric analysis of corruption on FDI}

Having studied the impact of corruption on FDI using a parametric model, in this section we report the results of two-sided and one-sided KS tests to analyse the possible differences in the 'more corrupt' and 'less corrupt' host countries in attracting FDI stock. Table 3 reports the test statistics generated from empirical FDI stock distributions as in equations (4) and (5) and the $p$ values reported in the parenthesis are obtained from the asymptotic distribution when one assumes that the FDI stocks from more and less corrupt countries are IID. ${ }^{14}$ The conclusions derived from using both the asymptotic distribution and the bootstrap are similar.

$<<$ Table 3 about here $>>$

The first rows of the three left columns in all parts of table 3 show that if we pool all the years together, we can reject the null hypothesis that the FDI stock distribution for the 'less corrupt' and 'more corrupt' countries are the same; and the alternative that the 'more corrupt' dominate the 'less corrupt' countries; whilst we cannot reject the alternative hypothesis that the 'less corrupt' dominate the 'more corrupt' countries at 5\% significant level. These results, taken together, show that the KS test indicates with 95\% confidence that the 'less corrupt' host countries stochastically dominate the 'more corrupt' host countries in the first degree. This means that, if we do not control for other variables, there is evidence of a significant negative impact of corruption on FDI stock for all quantiles of FDI distribution. This can also be shown by the cumulative distribution of the 'less corrupt' host country which lays to the right of the

\footnotetext{
${ }^{14}$ The results from relaxing the IID assumption using sub-sampling bootstrapping are very similar qualitatively to these observed from table 3 , hence is not reported here but are available from the authors upon request. The test statistics obtained from the empirical distributions for 'more corrupt' and 'less corrupt' host countries are the same under both IID and more generally assumption on sample distributions.
} 
'more corrupt' host country for all percentiles as in figure 1a. More specifically, any host country that has a corruption level higher than the average (i.e. 'more corrupt') would attract less FDI stock than a host country of the same percentile in the FDI stock cumulative distribution in the 'less corrupt' group. For instance, according to TI's CPI Japan is 'less corrupt' and it is at the $25^{\text {th }}$ percentile of the FDI distribution of the 'less corrupt' host countries. Whilst Italy is perceived as 'more corrupt' by TI and it is at the $25^{\text {th }}$ percentile of the FDI distribution for 'more corrupt' host countries. Between 1996 and 2003, the 'more corrupt' host country Italy on average received 1252 million US dollar less from Norway than Japan. This exemplifies a significant negative effect of corruption in reducing the unconditional FDI stock level. From figure 1a it can also be seen that the difference between 'more corrupt' and 'less corrupt' countries are more significant for lower quantiles. The most dramatic differences are found around the middle quantiles, whilst the differences are much less evident for the top quantiles of FDI stock distribution. This means that the relationship between corruption and FDI stock is heterogeneous among countries that are located at different quantiles of FDI distributions and when the mean value is used for analysis as in the traditional parametric studies, this heterogeneity would not be captured.

$<<$ Figure 1 about here $>>$

As shown in the previous section, apart from corruption, other factors such as the size of the host market, labour costs, trade, regulation in investment and in particular the location selection progress are also important in determining the level of FDI. Therefore, to take those into account we study how the 'more corrupt' and 'less corrupt' host countries would differ in attracting conditional FDI. Same as for the parametric analysis in the previous section, two sets of regression are performed using GDP per capita or GDP as alternative measure for market size in the FDI stock regression. In the first regression (i.e. conditional Heckman 1) GDP percapita is used, whilst in the second regression (i.e. conditional Heckman 2) GDP is used.

From the first row of the middle and right parts of Table 3, it is clear that when all the other factors are controlled for, we can reject the null that the FDI stock distributions for the 'more corrupt' and 'less corrupt' countries are the same and the alternative that the 'more corruption' dominate the 'less corrupt' countries in the first degree. However, we cannot reject the alternative that the 'less corrupt' dominate the 'more corrupt' countries only when GDP per capita is used as measure for market potential. This means that in half of the cases the KS test indicates that although the distributions of the 'more corrupt' and 'less corrupt' countries are significantly different from each other (i.e. as indicated by the rejection of the null), there is no clear dominance relation in first degree (i.e. as indicated by rejection of both alternatives). More explicitly, it means there is no longer a clear dominance relationship between the 'more corrupt' and 'less corrupt' host countries in attracting conditional FDI stock when all observations are pooled together.

Figures $1 \mathrm{~b}$ and $1 \mathrm{c}$ show that, for the lower quantiles of the FDI stock distribution, corruption would reduce the level of FDI stock. For instance, let us revisit the earlier example, after 
controlling for the other factors, between 1996 and 2003 the 'less corrupt' host country Japan on average would attract 1.76 million US dollar more in conditional FDI stock than the 'more corrupt' host country Italy. ${ }^{15}$ This shows that after controlling for other factors, the impact of corruption on FDI stock weakened dramatically.

However, for the top 20 percentile the negative impact cannot be identified. For instance, the bilateral FDI stock from Norway to Finland and Norway to Brazil fall into the top 20 percentile of the FDI stock distributions for 'less corrupt' and 'more corrupt' host countries respectively. Between 1996 and 2003 after controlling for the other factors on average the 'less corrupt' host country Finland attracted 0.43 (0.33) million US dollars less conditional FDI than the 'more corrupt' host country Brazil from Norway when GDP per capita and GDP are used as measures of market size in the FDI stock regression, respectively.

The intersection between the conditional cumulative FDI stock distribution curves of the 'more corrupt' and 'less corrupt' countries is around $70^{\text {th }}$ percentile. This means if any study that uses the dataset from the bottom 70 percentiles of the FDI stock distribution, a negative impact of corruption could be identified, however, if the top 20 percentiles of dataset is used, no significant negative impact of corruption could be identified. This provides more evidence that the relationship between corruption and conditional FDI is not at all homogenous and that the traditional parametric approach may not be always adequate in modelling the relationship between corruption and FDI. Also, such heterogeneity may provide an explanation for the conflictive or inclusive results observed in earlier parametric studies.

Furthermore, the second to ninth rows of the left column of Table 3 show that, before 2000, without controlling for other factors that might affect FDI, a 'less corrupt' host country attracts a higher level of FDI stock than a 'more corrupt' host country not only on average but also for any given percentile. The stochastic dominance relationship between the 'more corrupt' and 'less corrupt' host countries is less clear post 2000. This result holds also for conditional FDI, and is represented by the second to ninth rows of the middle and the right hand side columns of Table 3. These show that the OECD Anti-bribery convention does not make all MNEs more averse towards corruption when making their FDI level choices, and is different from what we observed earlier on in our parametric analysis. Combining these results with the ones obtained from the parametric analysis, we can conclude that although the OECD Anti-bribery convention on average makes MNEs more averse to corruption in the host country when choosing their level of FDI investment, this increasing of aversion towards corruption does not apply to all MNEs. This provides empirical support for TI's claim about the lack of effectiveness of the convention in altering MNEs' attitude towards corruption.

For a sensitivity analysis, we use the World Bank Government Indicator in place of CPI as measure of corruption. The results are generally in line with earlier observations from the parametric and non-parametric methods and are available upon request.

${ }^{15}$ The 1.76 million US dollar figure is derived from when GDP per capital is used as measure for market size in the FDI stock regression. On average Japan would attract 1.65 million US dollar more conditional FDI than Italy when GDP is used for market size in the regression. 


\section{Conclusion}

In this paper we have found that the overall effect of corruption is significantly negative on the likelihood of FDI taking place. Our results complement the findings of Javorcik and Wei (2009) and Hakkala et al. (2008), and imply that not only can corruption negatively affect the probability of FDI at the individual firm level (as in these papers), but it can also affect MNEs' FDI choices at the aggregate level. After correcting for MNEs' location choice the result indicates a positive impact of corruption on the levels of FDI stocks, thus providing some support for the existence of the 'helping-hand' role of corruption.

Using non-parametric methods we also show that the impact of corruption on FDI stock is not homogenous. In particular, for the top percentile of FDI stock distributions, the impact of corruption on FDI may not be negative after controlling for other relevant factors such as MNEs' location choice, market size, and factor costs between 1996 and 2003.

Finally, using both parametric and non-parametric methods we provide empirical support for the conclusion of Transparency International's report that the OECD Anti-bribery Convention has had only limited impact in making MNEs' more averse to corruption in the host countries.

In terms of policy implications, both parametric and non-parametric studies show that corruption affects MNEs' choices of FDI differently. In particular, the parametric study indicates a higher level of corruption would deter FDI from taking place, however once a country is selected as the host country, a higher level of corruption would not deter FDI. The non-parametric study indicates the impact of corruption on FDI stock is heterogeneous and depends on the location (in terms of percentiles) of the host country in the conditional FDI stock distribution. A higher level of corruption would discourage FDI stock for countries in the lower quantiles of the FDI distribution, whilst this negative effect cannot be found for countries in the top quantiles. This implies that in order to promote FDI governments should adopt different approaches conditional on the specific situation of their country. For instance, reducing corruption would be a particularly useful strategy for countries that have not been selected as FDI host countries before, but would be less efficient in promoting FDI stock if the country has already been chosen as FDI host country and is in the top quantiles of FDI stock distribution. Indeed, for those developing countries which may have low FDI, (such as Venezuela in our sample) controlling for corruption still should be viewed as a good strategy to attract FDI and the World Bank and TI's initiative to reduce corruption should be continuously pursued. However, for countries with a high level of corruption and FDI (such as China) reducing corruption would not necessarily induce higher FDI. This does not mean that controlling corruption in these countries is unimportant, but rather that it is still important for the country's social and political development rather than for the mere economic aspect of the matter. The discussion and analysis of these latter implications are beyond the scope of this paper, however, they may constitute topic for further research. 


\section{Acknowledgements:}

We would like to thank two referees, co-editor of the journal, Toke Aidt, Matthew Cole, Robert Elliott, Cillian Ryan, Toby Kendall and Eric Strobl, for their useful comments on earlier version of this paper and financial support from Leverhulme Trust Grant code F/00094/BH. 


\section{Tables:}

Table 1: Summary statistics

\begin{tabular}{|c|c|c|c|c|c|}
\hline & Mean & Std. Dev. & Min. & Max. & Obs. \\
\hline FDI stock & 2052.62 & 1472.45 & 2.00 & 4722 & 6411 \\
\hline Prob. Stock & 0.71 & 0.45 & 0 & 1 & 8660 \\
\hline Inverse TI's CPI & -5.54 & 2.50 & -10 & -0.57 & 8660 \\
\hline
\end{tabular}

FDI stock level is in millions of US dollar at 1999 price.

Table 2: Parametric estimation results

\begin{tabular}{|c|c|c|c|c|}
\hline & $\begin{array}{l}\text { FDI likelihood } \\
\text { (1) }\end{array}$ & $\begin{array}{l}\text { FDI Likelihood } \\
(2)\end{array}$ & $\begin{array}{l}\text { FDI Stock Heckman } \\
\text { (1) }\end{array}$ & $\begin{array}{l}\text { FDI Stock Heckman } \\
(2)\end{array}$ \\
\hline Corruption & $\begin{array}{l}-0.253^{* * *} \\
(-7.45)\end{array}$ & $\begin{array}{l}-0.253^{* * *} \\
(-7.48)\end{array}$ & $\begin{array}{l}0.108^{* * *} \\
(4.88)\end{array}$ & $\begin{array}{l}0.0696^{* * *} \\
(3.85)\end{array}$ \\
\hline Population & $\begin{array}{l}0.376^{* * *} \\
(6.13)\end{array}$ & $\begin{array}{l}0.375^{* * *} \\
(6.13)\end{array}$ & & \\
\hline Labour cost & $\begin{array}{l}-0.0125 \\
(-0.85)\end{array}$ & $\begin{array}{l}-0.0132 \\
(-0.89)\end{array}$ & $\begin{array}{l}-0.000252 \\
(-0.02)\end{array}$ & $\begin{array}{l}-0.00229 \\
(-0.21)\end{array}$ \\
\hline Openness & $\begin{array}{l}0.0000744 \\
(0.07)\end{array}$ & $\begin{array}{l}0.0000377 \\
(0.03)\end{array}$ & $\begin{array}{l}-0.000342 \\
(-0.40)\end{array}$ & $\begin{array}{l}-0.000153 \\
(-0.19)\end{array}$ \\
\hline Tax & $\begin{array}{l}-0.00710 \\
(-1.02)\end{array}$ & $\begin{array}{l}-0.00671 \\
(-0.97)\end{array}$ & $\begin{array}{l}-0.0110^{* *} \\
(-2.87)\end{array}$ & $\begin{array}{l}-0.0122^{* *} \\
(-3.23)\end{array}$ \\
\hline Anti-bribery & $\begin{array}{l}0.0835^{* * *} \\
(3.64)\end{array}$ & $\begin{array}{l}0.0824^{* * *} \\
(3.60)\end{array}$ & $\begin{array}{l}-0.0802^{* * *} \\
(-3.88)\end{array}$ & $\begin{array}{l}-0.0652^{* * *} \\
(-3.30)\end{array}$ \\
\hline Restriction & $\begin{array}{l}0.0229 \\
(0.36)\end{array}$ & $\begin{array}{l}0.0243 \\
(0.38)\end{array}$ & $\begin{array}{l}-0.109^{* * *} \\
(-4.80)\end{array}$ & $\begin{array}{l}-0.103^{* * *} \\
(-4.76)\end{array}$ \\
\hline Democracy & $\begin{array}{l}-0.00481 \\
(-0.49)\end{array}$ & $\begin{array}{l}-0.00534 \\
(-0.55)\end{array}$ & $\begin{array}{l}0.00255 \\
(0.38)\end{array}$ & $\begin{array}{l}0.00192 \\
(0.30)\end{array}$ \\
\hline GDP Growth & $\begin{array}{l}0.00380 \\
(0.42)\end{array}$ & & & \\
\hline Fixed Capital Growth & & $\begin{array}{l}0.000306 \\
(1.29)\end{array}$ & & \\
\hline GDP per Capita & & & $\begin{array}{l}0.0701^{* *} \\
(3.29)\end{array}$ & \\
\hline GDP & & & & $\begin{array}{l}0.0521^{* *} \\
(3.04)\end{array}$ \\
\hline Constant & $\begin{array}{l}-6.833^{* * *} \\
(-5.84) \\
\end{array}$ & $\begin{array}{l}-6.895^{* * *} \\
(-5.88) \\
\end{array}$ & $\begin{array}{l}8.290^{* * *} \\
(35.37) \\
\end{array}$ & $\begin{array}{l}7.117^{* * *} \\
(14.16)\end{array}$ \\
\hline $\begin{array}{l}\text { Heckman Location } \\
\text { Selection }\end{array}$ & & & & \\
\hline Corruption & & & $\begin{array}{l}-0.153^{* * *} \\
(-10.00)\end{array}$ & $\begin{array}{l}-0.153^{* * *} \\
(-10.00)\end{array}$ \\
\hline Population & & & $\begin{array}{l}0.205^{* * *} \\
(9.90)\end{array}$ & $\begin{array}{l}0.205^{* * *} \\
(9.90)\end{array}$ \\
\hline Labour Cost & & & $\begin{array}{l}-0.0147 \\
(-1.55)\end{array}$ & $\begin{array}{l}-0.0147 \\
(-1.55)\end{array}$ \\
\hline Openness & & & $\begin{array}{l}-0.00113 \\
(-1.51)\end{array}$ & $\begin{array}{l}-0.00113 \\
(-1.51)\end{array}$ \\
\hline Tax & & & $\begin{array}{l}-0.00639^{*} \\
(-1.98)\end{array}$ & $\begin{array}{l}-0.00639^{*} \\
(-1.98)\end{array}$ \\
\hline Anti-bribery & & & $\begin{array}{l}0.0569^{* * *} \\
(3.36)\end{array}$ & $\begin{array}{l}0.0569^{* * *} \\
(3.36)\end{array}$ \\
\hline Restriction & & & $\begin{array}{l}0.0282 \\
(1.47)\end{array}$ & $\begin{array}{l}0.0282 \\
(1.47)\end{array}$ \\
\hline Democracy & & & $\begin{array}{l}-0.00148 \\
(-0.25)\end{array}$ & $\begin{array}{l}-0.00148 \\
(-0.25)\end{array}$ \\
\hline GDP per capita & & & $\begin{array}{l}0.00383 \\
(0.64)\end{array}$ & $\begin{array}{l}0.00383 \\
(0.64)\end{array}$ \\
\hline Constant & & & $\begin{array}{l}-3.692^{* * *} \\
(-8.60) \\
\end{array}$ & $\begin{array}{l}-3.692^{* * *} \\
(-8.60)\end{array}$ \\
\hline $\begin{array}{l}\text { Mills } \\
\text { Lambda }\end{array}$ & & & $\begin{array}{l}-1.160^{* * *} \\
(-5.15)\end{array}$ & $\begin{array}{l}-0.701^{* *} \\
(-2.59)\end{array}$ \\
\hline
\end{tabular}

$t$ statistics in parentheses

${ }^{*} p<0.05,{ }^{* *} p<0.01,{ }^{* * *} p<0.001$ 
Table 3: Non-parametric test results (asymptotic $p$-values)

\begin{tabular}{|c|c|c|c|c|c|c|c|c|c|}
\hline \multicolumn{10}{|l|}{ TI CPI } \\
\hline & No difference & $\begin{array}{l}\text { Less corrupt } \\
\text { dominate }\end{array}$ & $\begin{array}{l}\text { More corrupt } \\
\text { dominate }\end{array}$ & No difference & $\begin{array}{l}\text { Less corrupt } \\
\text { dominate }\end{array}$ & $\begin{array}{l}\text { More corrupt } \\
\text { dominate }\end{array}$ & No difference & $\begin{array}{l}\text { Less corrupt } \\
\text { dominate }\end{array}$ & $\begin{array}{l}\text { More corrupt } \\
\text { dominate }\end{array}$ \\
\hline All years & $\begin{array}{l}0.1240 \\
(0.000)\end{array}$ & $\begin{array}{c}0.0000^{* *} \\
(1.000)\end{array}$ & $\begin{array}{l}0.1240 \\
(0.000)\end{array}$ & $\begin{array}{l}0.0931 \\
(0.000)\end{array}$ & $\begin{array}{c}-0.0375^{*} \\
(0.013)\end{array}$ & $\begin{array}{l}0.0931 \\
(0.000)\end{array}$ & $\begin{array}{l}0.0920 \\
(0.000)\end{array}$ & $\begin{array}{c}-0.0580 \\
(0.000)\end{array}$ & $\begin{array}{l}0.0820 \\
(0.000)\end{array}$ \\
\hline 1996 & $\begin{array}{l}0.1930 \\
(0.000)\end{array}$ & $\begin{array}{c}0.0000^{* *} \\
(1.000)\end{array}$ & $\begin{array}{l}0.1930 \\
(0.000)\end{array}$ & $\begin{array}{l}0.1233 \\
(0.004)\end{array}$ & $\begin{array}{c}-0.0358^{* *} \\
(0.599)\end{array}$ & $\begin{array}{l}0.1233 \\
(0.002)\end{array}$ & $\begin{array}{l}0.1233 \\
(0.004)\end{array}$ & $\begin{array}{c}-0.0596^{* *} \\
(0.242)\end{array}$ & $\begin{array}{l}0.1233 \\
(0.002)\end{array}$ \\
\hline 1997 & $\begin{array}{l}0.2088 \\
(0.000)\end{array}$ & $\begin{array}{c}-0.0017^{* *} \\
(0.998)\end{array}$ & $\begin{array}{l}0.2088 \\
(0.000)\end{array}$ & $\begin{array}{l}0.1873 \\
(0.000)\end{array}$ & $\begin{array}{c}-0.0254^{* *} \\
(0.779)\end{array}$ & $\begin{array}{l}0.1873 \\
(0.000)\end{array}$ & $\begin{array}{l}0.1821 \\
(0.000)\end{array}$ & $\begin{array}{c}-0.0464^{* *} \\
(0.434)\end{array}$ & $\begin{array}{l}0.1821 \\
(0.000)\end{array}$ \\
\hline 1998 & $\begin{array}{l}0.1592 \\
(0.000)\end{array}$ & $\begin{array}{c}-0.0012 * * \\
(0.999)\end{array}$ & $\begin{array}{l}0.1592 \\
(0.000)\end{array}$ & $\begin{array}{l}0.1639 \\
(0.000)\end{array}$ & $\begin{array}{c}-0.0482^{* *} \\
(0.398)\end{array}$ & $\begin{array}{l}0.1639 \\
(0.000)\end{array}$ & $\begin{array}{l}0.1639 \\
(0.000)\end{array}$ & $\begin{array}{c}-0.0588^{* *} \\
(0.254)\end{array}$ & $\begin{array}{l}0.1639 \\
(0.000)\end{array}$ \\
\hline 1999 & $\begin{array}{l}0.1211 \\
(0.001)\end{array}$ & $\begin{array}{c}-0.0131 * * \\
(0.915)\end{array}$ & $\begin{array}{l}0.1211 \\
(0.001)\end{array}$ & $\begin{array}{l}0.1300 \\
(0.004)\end{array}$ & $\begin{array}{c}-0.0531 * * \\
(0.367)\end{array}$ & $\begin{array}{l}0.1300 \\
(0.002)\end{array}$ & $\begin{array}{l}0.1294 \\
(0.004)\end{array}$ & $\begin{array}{c}-0.0888^{* *} \\
(0.061)\end{array}$ & $\begin{array}{l}0.1294 \\
(0.003)\end{array}$ \\
\hline 2000 & $\begin{array}{c}0.0673^{* *} \\
(0.170)\end{array}$ & $\begin{array}{c}-0.0121 * * \\
(0.927)\end{array}$ & $\begin{array}{c}0.0673^{* *} \\
(0.095)\end{array}$ & $\begin{array}{c}0.0833^{* *} \\
(0.164)\end{array}$ & $\begin{array}{c}-0.0833^{* *} \\
(0.082)\end{array}$ & $\begin{array}{c}0.0333^{* *} \\
(0.670)\end{array}$ & $\begin{array}{c}0.1028^{*} \\
(0.037)\end{array}$ & $\begin{array}{c}-0.1028^{*} \\
(0.022)\end{array}$ & $\begin{array}{c}0.0278^{* *} \\
(0.757)\end{array}$ \\
\hline 2001 & $\begin{array}{c}0.0750^{* *} \\
(0.134)\end{array}$ & $\begin{array}{c}-0.0330^{* *} \\
(0.569)\end{array}$ & $\begin{array}{c}0.0705^{* *} \\
(0.076)\end{array}$ & $\begin{array}{l}0.1154 \\
(0.007)\end{array}$ & $\begin{array}{l}-0.1154 \\
(0.004)\end{array}$ & $\begin{array}{c}0.0464 * * \\
(0.413)\end{array}$ & $\begin{array}{l}0.1202 \\
(0.004)\end{array}$ & $\begin{array}{l}-0.1202 \\
(0.003)\end{array}$ & $\begin{array}{c}0.0387^{* *} \\
(0.542)\end{array}$ \\
\hline 2002 & $\begin{array}{c}0.0841 * \\
(0.043)\end{array}$ & $\begin{array}{c}-0.0150^{* *} \\
(0.890)\end{array}$ & $\begin{array}{c}0.0841 * \\
(0.025)\end{array}$ & $\begin{array}{l}0.1169 \\
(0.009)\end{array}$ & $\begin{array}{c}-0.1169 \\
(0.006)\end{array}$ & $\begin{array}{c}0.0711 * \\
(0.147)\end{array}$ & $\begin{array}{l}0.1356 \\
(0.001)\end{array}$ & $\begin{array}{c}-0.1356 \\
(0.001)\end{array}$ & $\begin{array}{c}0.0628 * * \\
(0.225)\end{array}$ \\
\hline 2003 & $\begin{array}{l}0.1057 \\
(0.005)\end{array}$ & $\begin{array}{c}-0.0058^{* *} \\
(0.983) \\
\end{array}$ & $\begin{array}{l}0.1057 \\
(0.003)\end{array}$ & $\begin{array}{l}0.0949^{*} \\
(0.042)\end{array}$ & $\begin{array}{c}-0.0949 * \\
(0.025) \\
\end{array}$ & $\begin{array}{c}0.0768 * * \\
(0.089)\end{array}$ & $\begin{array}{c}0.1027^{*} \\
(0.022)\end{array}$ & $\begin{array}{c}-0.1027 * \\
(0.013) \\
\end{array}$ & $\begin{array}{c}0.0692^{* *} \\
(0.141) \\
\end{array}$ \\
\hline
\end{tabular}

* indicates the hypothesis cannot be rejected at $1 \%$

$* *$ indicates the hypothesis cannot be rejected at $5 \%$

1.p-values are in parenthesis.
2.In Conditional (Heckman 1) GDP per capita is used as measure for market size.

3.In Conditional (Heckman 2) GDP is used as measure for market size. 
Figure 1: The cumulative distribution of unconditional and conditional average FDI stock 1996-2003

a. Unconditional FDI stocks

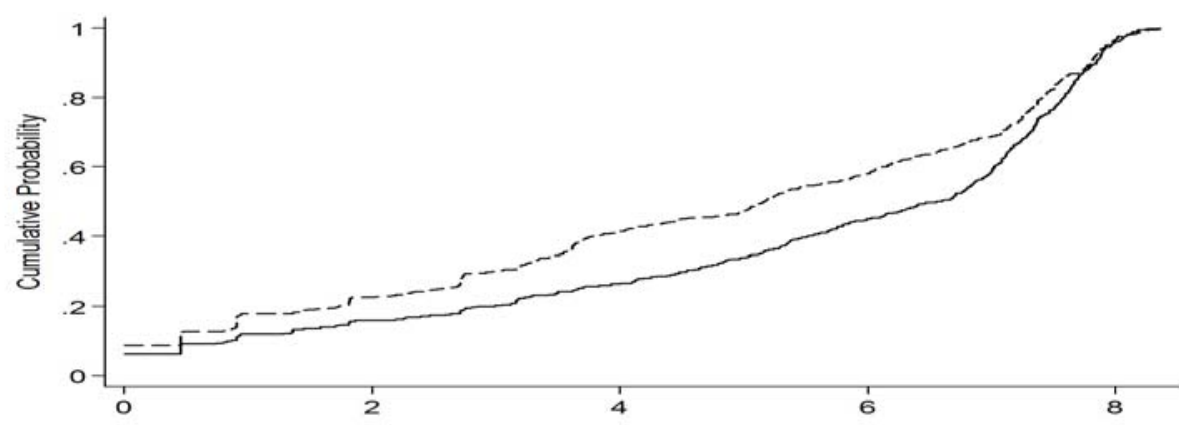

- - - - - - More corrupt countries

Less corrupt countries

b. Conditional FDI stocks (Heckman 1)

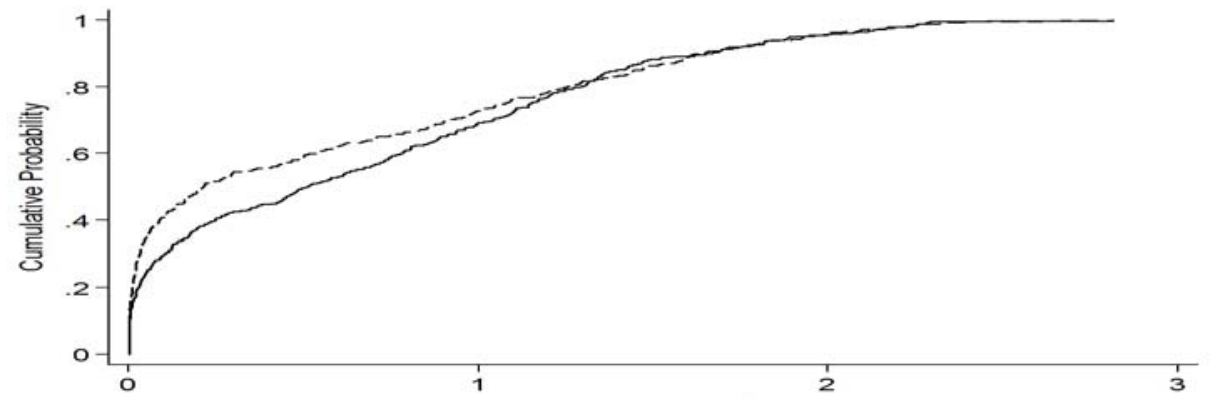

- - - - - More corrupt countries

Less corrupt countries

c. Conditional FDI stocks (Heckman 2)

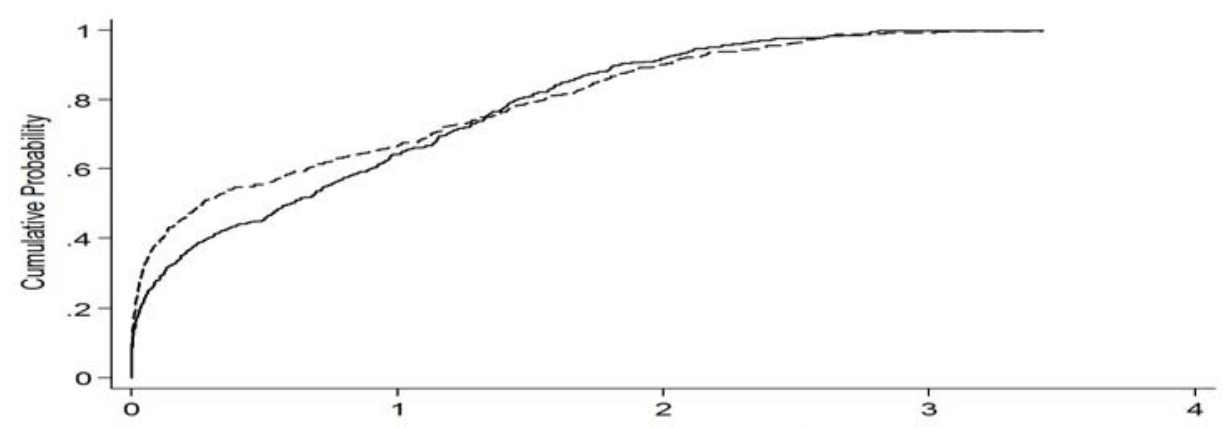

- - - - - - More corrupt countries Less corrupt countries 


\section{Appendix:}

The source country List:

Australia, Austria, Belgium, Canada, Czech Republic, Denmark, Finland, France, Germany, Greece, Hungary, Iceland, Ireland, Italy, Japan, Korea, Mexico, Netherlands, New Zealand, Norway, Poland, Portugal, Slovakia, Spain, Sweden, Switzerland, Turkey, United Kingdom, United States.

The host countries include:

Argentina, Australia, Austria, Belgium, Brazil, Bulgaria, Canada, Chile, China, Colombia, Czech Rep., Denmark, Egypt, Finland, France, Germany, Greece, Hong Kong, Hungary, Iceland, India, Indonesia, Iran, Ireland, Israel, Italy, Japan, Korea, Rep. of, Luxembourg, Malaysia, Mexico, Morocco, Netherlands, New Zealand, Norway, Philippines, Poland, Portugal, Russia, Singapore, Slovakia, South Africa, Spain, Sweden, Switzerland, Thailand, Turkey, Ukraine, United Arab Emirates, United Kingdom, United States, Venezuela. 


\section{References:}

Aidt, T., 2003. Economic analysis of corruption: a survey. The Economic Journal 113, 632-652.

Alan, H., Summers, R., Aten, B., 2006. Penn world table version 6.2. Center for International Comparisons of Production, Income and Prices at the University of Pennsylvania, Philadelphia.

Beck, P., Marher, M. W., 1986. A comparison of bribery and bidding in thin markets. Economic Letters 20, 1-5.

Bliss, C., Di Tella, R., 1997. Does competition kiss corruption. The Journal of Political Economy 105, 1001-1023.

Brainard, S. L., 1993. A simple theory of multinational corporations and trade with a trade off between proximity and concentration. NBER Working Paper, vol. 4269. National Bureau of Economic Research, Cambridge MA.

Bjorvatn, K., Soreide, T., 2005. Corruption and privatization. European Journal of Political Economy 21, 903-914.

Busse, M., Hefeker, C., 2007. Political risk, institutions and foreign direct investment. European Journal Political Economy 23, 397-415.

Campos, N. F., Estrin, S., Proto, E., 2010. Corruption as a barrier to entry: Theory and Evidence. IZA Research Paper, vol. 5243. Institute for the Study of Labour (IZA), Bonn.

China-Britain Business Council, 2005. CBBC: Helping you do business in China. China-Britain Business Council, London.

Control Risks and Simmons \& Simmons, 2006. International business attitudes to corruption: survey 2006. Control Risks and Simmons \& Simmons, Algiers, Baghdad, Copenhagen, Dallas, Erbil, Hong Kong, Kabul, Lagos and Mumbai.

Conover, W. J., 1999. Practical Nonparametric Statistics, Third ed. Wiley, New York.

Dalgic, E., Long, N. V., 2006, Corrupt local governments as resource farmers: the helping hand and the grabbing hand. European Journal of Political Economy 22, 115-138.

Delgado, M. A., Farinas, J.C., Ruano, R., 2002. Firm's productivity and the export market: a nonparametric approach. Journal of International Economices 57, 397-422.

Drabek, Z., Payne, W., 2001. The Impact of transparency on foreign direct investment. Staff Working Paper, vol. 99/02. World Trade Organization, Geneva.

Egger, P., Winner, H., 2005. Evidence on corruption as an incentive for foreign direct investment. European Journal of Political Economy 21, 932-952.

Egger, P., Winner, H., 2006. How corruption Influences foreign direct investment: a panel data study. Economic Development and Cultural Change 54, 459-486.

Goel, R. K., Nelson, M. A., Naretta, M. A., 2012. The internet as an indicator of corruption awareness. European Journal of Political Economy 28, 64-75.

Habib, M., Zurawicki, L., 2002. Corruption and foreign direct investment. Journal of International Business Studies 33, 291-307.

Hakkala, K. N., Norback, P., Svaleryd, H., 2008. Asymmetric effects of corruption on FDI: evidence from Swedish multinational firms. The Review of Economics and Statistics 90, 627-642.

Heckman, J., 1979. Sample selection bias as a specification error. Econometrica 47, 153-161.

Helpman, E., 1984. The factor content of foreign trade. Economic Journal 94, 84-94.

Helpman, E., 1985. Multinational corporations and trade structure. Review of Economic Studies 52, 443-57.

Helpman, E., Melitz, M. J., Yeaple, S. R., 2004. Exports versus FDI with heterogeneous firms. American Economics Review 94, 300-316. 
Horstmann, I. J., Markusen, J. R., 1992. Endogenous market structures in international trade (natura facit saltum). Journal of International Economics 32, 109-129.

International Labour Organisation (ILO), 2004. Key Indicators of the labour market. ESDS International, MIMAS, University of Manchester, Manchester. Internet posting: http://www.esds.ac.uk/international/access/access.asp

International Monetary Fund (IMF), 2004. IMF International financial statistics (IFS). ESDS International, MIMAS, University of Manchester, Manchester. Internet posting: http://www.esds.ac.uk/international/access/access.asp

Javorcik, B. S., Wei, S-J., 2009. Corruption and cross-border investment in emerging markets: firm-level evidence. Journal of International Money and Finance 28, 605-624.

Kaufmann, D., 1997. Corruption: the facts. Foreign Policy 107, 114-31.

Kaufmann, D., Kraay, A., Mastruzzi, M., 2005. Governance matters V: governance indicators for 1996-2005. World Bank Policy Research, vol. 3630. The World Bank, Washington DC.

McFadden, K. L. R., McFadden, D., 1991. A robust test for stochastic dominance. MIT Working paper, MIT, Cambridge MA.

Kolmogorov, A. N., 1933. Sulla determinazione empirica di una legge di distribuzione. Girnale dell' Istituto Italiano degli Attuari 4, 83-91.

Lambert-Mogiliansky, A., 2002. Why firms pay occasional bribes: the connection economy. European Journal of Political Economy 18, 47-60.

Lui, F. T., 1985. An equilibrium queuing model of bribery. Journal of Political Economy 93, 76081.

Linton, O., Maasoumi, E., Whang, Y-J., 2005. Consistent testing for stochastic dominance under general sampling schemes. Review of Economic Studies 72, 735-765.

Maasoumi, E., Heshmati, A., 2000. Stochastic dominance amongst Swedish income distributions. Econometric Reviews 19, 287-320.

Maasoumi, E., Milliment, D., 2003. Robust inference concerning recent trends in U.S. environmental quality. Journal of Applied Econometrics 20, 55-77.

McFadden, D., 1989. Testing for stochastic dominance. In Fomby, T., Seo, T.K. (Eds.), Studies in the Economics of Uncertainty, Springer-Verlag, New York, pp. 113-134.

Nijman, T., Verbeek, M., 1992. Nonresponse in panel data: the impact on estimates of a life cycle consumption function. Journal of Applied Econometrics 7, 243-257.

Organisation for Economic Development and Cooperation, 2004. OECD International Direct Investment Statistics dataset. ESDS International, MIMAS, University of Manchester, Manchester. Internet posting: http://www.esds.ac.uk/international/access/access.asp

Organisation for Economic Development and Cooperation, 2004. OECD International Trade by Commodities Statistics dataset. ESDS International, MIMAS, University of Manchester, Manchester. Internet posting: http://www.esds.ac.uk/international/access/access.asp

Organisation for Economic Development and Cooperation, 2005. International Investment Perspectives 2005. OECD, Paris.

Organisation for Economic Development and Cooperation, 2006. The OECD fights corruption. OECD, Paris.

Polity IV Project., 2006. Political regime characteristics and transitions: 1800-2006. SocietalSystems Research Inc. and Colorado State University, Colorado.

Saha, B., 2001. Red tape, incentive bribe and the provision of subsidy. Journal of Development Economics 65, 113-133.

Shleifer, A., Vishny, R., 1992. Pervasive shortage under socialism. The Rand Journal of Economics 23, 237-46.

Shleifer, A., Vishny, R., 1993. Corruption. The Quarterly Journal of Economics 108, 599-617.

Smirnov, N. V., 1933. Estimate of deviation between empirical distribution functions in two independent samples. Bulletin Moscow University 2, 3-16. 
Svensson, J., 2003. Who must pay bribes and how much: evidence from a cross-section of firms. Quarterly Journal of Economics 118, 207-230.

Svensson. J., 2005. Eight questions about corruption. Journal of Economic Perspectives 19, 1942.

Tanzi. V., 1998. Corruption around the world: causes, consequences, scope and cures. IMF Staff Paper 45, 559-594.

Transparency International, 2005. Transparency International bribe payers index (BPI) 2005. Transparency International, Berlin.

Transparency International, 2005. Transparency International Corruption perceptions index (CPI) 2005. Transparency International, Berlin.

Transparency International, 2006. Transparency International bribe payers index (BPI) 2006. Transparency International, Berlin.

Transparency International, 2006. Enforcement of OECD anti-bribery convention still deficient despite progress: new report. Transparency International, Berlin.

Transparency International, 2006. Transparency International Global Corruption report 2006. Transparency International, Berlin.

Transparency International, 2010. Transparency International bribe payers index (BPI) 2010. Transparency International, Berlin.

United Nations Conference on Trade and Development, 1993. World investment report 1993. UNCTD, United Nations, New York and Geneva.

United Nations Conference on Trade and Development, 1999. World investment report 1999. UNCTD, United Nations, New York and Geneva.

United Nations Conference on Trade and Development, 2003. World investment report 2003. UNCTD, United Nations, New York and Geneva.

United Nations Conference on Trade and Development, 2005. Prospects for foreign direct investment and the strategies of transnational corporations 2005-2008. UNCTD, United Nations, New York and Geneva.

United Nations Conference on Trade and Development, 2006. World investment report 2006. UNCTD, United Nations, New York and Geneva.

Verbeek. M., Nijman, T., 1992. Testing for selectivity bias in panel data models, International Economic Review 33, 681-703.

Wei, S-J., 1997. Why is corruption so much more taxing than tax? arbitrariness kills. Working Paper, vol. 6255. National Bureau of Economic Research, Cambridge MA.

Wei, S-J., 2000a. How taxing is corruption on international investors. The Review of Economics and Statistics 82, 1-11.

Wei, S-J., 2000b. Local corruption and global capital flows. Brooking Papers on Economic Activity 31, 303-354.

Wei, S-J., 2000c. Does corruption relieve foreign investors of the burden of taxes and capital Controls. In: Hines, J. (Eds.), International Taxation and Multinational Activity, University of Chicago Press, Chicago, pp. 73-88.

Wheeler, D., Mody, A., 1992. International investment location decisions: the case of U.S. firms. Journal of International Economics 33, 57-76.

Wooldridge, J. M., 2002. Econometric analysis of cross section and panel data. The MIT Press, Cambridge MA.

World Bank., 1999. Administrative barriers to investment in Africa: the red tape analysis. FIAS, Washington DC.

World Bank, 2005. World development indicators (WDI), ESDS International, MIMAS, University of Manchester, Manchester. Internet posting: http://www.esds.ac.uk/international/access/access.asp 